\title{
Effect of Supply Chain Resilience on Organizational Performance among Selected Manufacturing Firms in Nairobi, Kenya
}

\author{
Peter Kosgey \\ Lecturer, Graduate School. University of Kigali-Rwanda
}

\begin{abstract}
Every organizational main reason, together with supply chain resilience, ought to eventually lead to improved organizational performance. Those firms that have became resilient endeavor such proactive efforts as an essential or vital point of administrative consideration, are in a better position to enjoy a longer survival with manageability. The purpose of this study was to establish the effect of supply chain resilience on organizational performance. The resource-based view theory (RVB) was used to ground this study. Explanatory research design was adopted, of a survey method conducted on selected manufacturing firms in Nairobi. The target population of this study was 478 , Self-administered questionnaires were distributed to 237 purchasing managers. Multiple linear regression analysis was conducted to test what was hypothesized in the study and specifically to establish the effect between the variables. The statistical results revealed that environmental uncertainty and information management had a positive and significant effect on organizational performance $(\beta=0.450 ; p<0.05 ; \beta=0.230$; $p<0.05$ ). This research in its conclusion showed the existence of interdependence of supply chain resilience with organizational performance. The study recommends that organizations should fully recognize the nature of fundamental inventory network resilience and have proceeded with center around looking for effective changes. Flexibility could be additionally contemplated with regards to dyadic purchaser provider connections.
\end{abstract}

Keywords: Environmental Uncertainty, Information Management, Organizational Performance and Resource Based View theory.

\section{INTRODUCTION}

ny firm's principal purpose, inclusive of supply chain Aresilience, ought to at last prompt improved organizational performance. Organizational execution incorporates three different types of a firms' outcome, monetary performance (profits, income on wealth profitability threshold) marketwise development (overall industry markets share and sales) shareholders' payout ratio (inclusive of investors income) and overall competitive position. In understanding information management in social and organizational context, Cook, et al., (2011), posited that manufacturing organizations are influenced by collaboration with innovation. Associations drawn upon available organizational properties in IT advancement and purpose. Contrary to that, the available firms' properties are very important in knowing the effects of innovation. Lambert et al., (2007) propose the thought of developmental setting, that is "the arrangement of institutional courses of action and psychological symbolisms that educate the actors' useful and thinking routine in organizations.

Effectiveness is one type of performance indicator in an organization it includes three particular territories of organizational results: budgetary performance (benefits, return on resources, rate of profitability, and so forth) showcase performance (deals, piece of the overall industry and so on) shareholders return (add up to investors return, financial esteem included and so on). The dimensionality of firms' performance emerges out of the partnership that cooperate with and inside the association, the heterogeneity of organizations assets, situations and the key decisions and the varieties of working extra time. Organizational performance centers around the supply chain perceivability, adaptability, coordinated effort and client esteem. This alludes to the value of the supply chain for the particular clients and has been appeared by Wieland and Wallenburgs (2012) to be a commanding performance measurement coming about because of flexibility. It likewise alludes to various perspectives like decreased vulnerability, controls, conformance to client determinations and consumer loyalty.

\section{Statement of the problem}

According to Li et al., (2006), organizational performance has been estimated utilizing both financial and market criteria, including return on investment (ROI), market criteria, marginal return from sale, the development of ROI, growth of return, growth of the market share, and general aggressive position. Those organizations that are resilient attempt such proactive effort a focal point of firms consideration were better situated for long term survival and supportability Mentzer et al., (2008). According to Zeithaml et al., (2006), satisfaction or dissatisfaction is a measure or evaluation of a supply chain's ability to meet a customer's need or expectations. Most of the manufacturing firms experience delays in their supply chain hence does not meet the customers' needs and requirements.

Supply chain is an important aspect in the world economy. In addition, their intricacy together with its important role has triggered worries amongst both the business firms and the governments in looking into big distribution. These better procedures are requirements based on resilience to assemble 
agile, open and broadened system (Li et al., 2006). Supply chain resilience offers a blue print for resilience through open private partnership, strategical policy with information technology together with the need for organizations to put it in place. There is need for Supply chain and businesses to develop resilient that is better at detecting and reacting to better dangers previously they cause intense, managed and perhaps disastrous budgetary outcomes. Resilient supply chain depends on prescience situation modeling and consistency, operational measurements are valuable as they seem to be taking a look at the past or today; the presence of sorted out and well organized databases is a key wheel of enterprise performance (Christopher and Peck, 2004). Firms should center on the control of critical environmental resources in an effort to negotiate the uncertainty and hostility of their environments. Although resilience has been documented in developed countries, it is not known how supply chain resilience influences performance in manufacturing firms in Kenya. The study therefore, aimed to research on the effect of supply chain resilience on organizational performance of manufacturing firms (Christopher and Peck, 2004).

\section{THEORETICAL REVIEW}

Barney (2007) specified that resource based view (RBV) can be connected to both inward and outer components of an organizations supply chain resilience. While, Acedo et al., (2006) expressed that RBV is commonly connected to oversee organizations deliberately. RBV analyzes those assets and capacities of the firm as to create above ordinary rates of return and accomplish an economical upper hand. Assets can be isolated as substantial and elusive assets ordered as human, data innovation, and capital, gear and learning assets. So as to accomplish feasible upper hand assets should be profitable, uncommon, not substitutable, and efectively inmitatible. Thus, as indicated by RBV, assets that are important and exorbitant to duplicate give a wellspring of maintained upper hand (Ketchen \& Hult, 2007)

According to RBV, the recognizable proof and ownership of inside key assets adds to a company's capacity to make and keep up an upper hand, Crook et al,. (2008). The dynamic viewpoint of RBV clarifies a company's upper hand in changing situations and, subsequently, encourages a superior comprehension of how firm production network deftness impacts execution (Priem and Butler 2001). An integrative perspective discovers its hypothetical defense in the current stream of writing on request supply reconciliation (Juttner $e t$ al., 2010). It is likewise upheld by the way that no single capacity alone, however solid it is, is adequate for accomplishing a feasible upper hand. Supply chain resilince is dynamic capacity and an asset that prompt a few positive execution, versatility is critical to building up a vital arrangement that is manageable and equipped for delivering comes about that are superior to less flexible contenders.

\section{III.REVIEW OF LITERATURE}

\section{Concept of Organizational performance}

In studies of organizations, which are frequently characterized as having enterprise performance as its essential concentration, yet the possibility that performance is to be anticipated, comprehended, and formed in common place all round the field. Such a stance is additionally held onto as a code of appropriate conduct. Firms performance measures to what extend has the organization attained its goals in terms of the market share in relation to its financial expectation ( $\mathrm{Yu}$ et al., 2018). The importance of achieving SCR is essentially in efficiency attainment, inventories reduction and production time, while long term goals are to expand piece of the pie and benefits for all individuals from the supply chain (Tan, 2002). Financial posting serves as an indicator in an organization and assessing a firm's performance after a given period of time (Linnenluecke \& Griffiths, 2010).

The information about clear determinants of contrasts in performance diffuses through a populace of contenders and in this way has a tendency to wipe out variety in both the determinants and their effects. The hypothetical thoughts and analytical models that are usually utilized overlook an assortment of criticism circles that are probably going to be imperative. The informations that are utilized to record firms histories regularly depend on review of information, review that is probably going to remake the past to make it steady with ensuring performance comes about, customary story lines, and current beliefs. The asset based view (RBV) of the firm gives essential experiences in assessing how well an organization has performed and how to sustain the performance over time. RBV states that organizations acquire upper hand by aggregating inward assets and abilities that are uncommon, profitable, and hard to mirror (Barney, 1991). Teece et al., (2007) build up the RBV approach above and beyond by figuring the dynamic abilities point of view. As per their investigation, the expression "dynamic" alludes to the ability to restore skills in order to accomplish harmoniousness with the ecological uncertainty. Endeavors to satisfy the implicit guarantee of the code, the expectations of managers, the rationale of performance change, and the desire of scholars of firms' adjustment experience a fundamental complexity; however, distinguishing the genuine causal structure of firm's performance phenomena based on the inadequate data derived by verifiable experience is hazardous. Analysts of firm's performance infrequently practice exploratory control over indicator factors (Johnson et al., 2008).

Subsequently, they face issues of finding sufficient recorded information and of requesting and translating the account of data. The records of naturally happening histories of enterprise performance are really hard to interpret (Tan, 2006). Any perception based organizational history is overflowing with undaunted ambiguities that can disappoint the efforts of measurable and interpretive imaginative ability 
to recognize causal connections among historical occasions. Without an effort to be far reaching, we say three of the more pertinent issues engaged with understanding variation in firms' performance. Supply chain resilience short-term goals are purposed to attain productive with diminish process and inventory holding time, while long-term goals are aimed at expounding the market share and benefits individual derive from the supply chain (Tan, 2006). Financial statistics serve as a device for organizational comparison and evaluating a firm performance in due time ( $\mathrm{Li}$ et al., 2006). Olavarrieta and Ellinger (1997) demonstrate that logistic ability meets all requirements to be an unmistakable capacity (the one prompting practical upper hand) by surveying attributes, for example, included esteem, irregularity, and hard for imitating. Mentzer et al., (2004) insisted that logistics capacities assume a particular part in the integrative key process because of the normal advantages of enhancing firm productivity and viability prompting long-term firm benefit and survival.

\section{Supply chain resilience}

Supply chain Resilience is the ability of an organization supply chain to get ready for uncertain future, react to disturbances, and bounce back from it at the right time by keeping up congruity of activities at the expected threshold of expectation. The disruption talked about here are important and of high profile, and if happened, the outcomes could be disastrous for organization and they may wind up in insolvency or horrible misfortune in benefits. Moreover, "in the turbulent nature of markets and unpredictable near future, supply chain inconsistency has become a bone of contention to some business entities and proper studies on resilient supply chain are yet to be undertaken" (Christopher and Peck, 2004). The supply chain disturbances include, unfavorable weather(windstorm/tornado, flooding, snow and so forth), spontaneous blackout of IT or media transmission frameworks, transport system interruption Earthquake/torrent, disappointment in benefit arrangement by an outsourcers, loss of ability/aptitudes, item quality episode volcanic powder cloud, indebtedness, common distress/strife, industrial instability, fire and cyber crimes" (Business Continuity Institute, 2011).

There are numerous definitions today characterizing lean production, "the meaning of lean generation is profoundly slippery" (Pettersen, 2009). One of the definition expresses that, "lean production is 'lean' since it utilizes less of everything contrasted with large scale manufacturing, a large portion of the human exertion in the industrial facility, a large portion of the assembling space, a large portion of the interest in apparatuses, a large portion of the building hours to build up another item in a fraction of the time. Additionally, it requires keeping far not as much as a large portion of the required stock nearby, brings about fewer imperfections, and produces a more prominent and consistently developing assortment of items (Womack et al., 1990). It is very obvious from the definition that waste is maintained as strategic distance from every one of the elements of the association.
Moreover, lean production comprises of four noteworthy parts to be specific mindfulness, quality affirmation, level of production and in the nick of time. Making and keeping up supply chain resilience isn't an onetime occasion it is a procedure. As a major aspect of this study effort, the author came up with a procedure stream to help organizations in their resilience journey. This process includes perusing the task, choosing a proper group, playing out the SCRAM appraisal, examining the information, approving the business case, at that point assessing results and re-evaluating.

A system without this resilience elements are not in a position to go around any disruption that may occur in the course. SCR is conceptualized as environmental uncertainty and information management.. More insight of the development of supply chain resilience is extrapolated below. Successful correspondence between firms can be described as certifiable, visit and including individual contacts (Chen and Paulraj, 2004). At all cost, deft conduct is a typical motivation behind why organizations neglect to accomplish elite. Collaboration involves the dynamic support by the performing artists required toward managing the relationship (Morris and Carter, 2005). In this way, participation goes past the stream of data inalienable to open connections.

\section{$H_{l}$ : Environmental uncertainty has no significant effect on organizational performance.}

$\mathrm{H}_{2}$ : Information management has no significant effect on organizational performance.

\section{RESEARCH METHODOLOGY}

The research design is the conceptual step in conducting research. It serves as a guide for data collection and measurement (Kothari, 2004). Explanatory research design was adopted while the sample size is 237. Inferential statistics were utilized to draw suggestions from the information as to the relapse display. Multiple linear regression analysis was applied in the study to test the hypotheses formulated and is expressed as:

$$
Y=\beta_{0}+\beta_{1} X_{1}+\beta_{2} X_{2}+\varepsilon
$$

Where,

$\mathrm{Y}=$ Organizational performance

$\mathrm{X}_{1}=$ Environmental uncertainty

$\mathrm{X}_{2}=$ Information management

$\beta_{0}=$ Constant

$\beta_{1}-\beta_{2}=$ Coefficient of estimates

$\varepsilon=$ Error tem

\section{STATISTICAL RESULTS}

Results in Table 1 revealed that there was a positive and significant correlation between environmental uncertainty and organizational performance $(\mathrm{r}=0.501, \mathrm{p}<0.05)$. More so, the correlation between information management and organizational performance had a positive and significant 
relationship at $(\mathrm{r}=0.582, \mathrm{p}<0.05)$. Therefore, it can be concluded that explanatory variables are positively correlated to organizational performance at $1 \%$ level of significance.

The findings of the multiple linear regression model revealed that supply chain resilience accounted for $46.7 \%$ of the variation in organizational performance $\left(R^{2}=0.467\right)$. The $F$ ratio of 28.732 with a p-value less than $5 \%$ level of significance further demonstrated that the model was fit to predict organizational performance as evidenced by the statistical findings.

The first hypothesis stated that there is no significant effect between environmental uncertainty and organizational performance. According to the findings of the study, environmental uncertainty had a positive coefficient of estimate that was statistically significant $(\beta=0.450 ; \mathrm{p}<0.05)$, indicating that it had a positive and significant effect on organizational performance. This therefore implies that a unit change in environmental uncertainty increases organizational performance by 0.450 units. This is so because as the firms invest in modern technology and market analysis, it translates to increased market share, reduced volatility and reduced environmental complexities which in turn enhance organizational performance.

The second hypothesis postulated that information management has no significant effect on organizational performance. Results showed that there was a positive effect between information management and organizational performance $(\beta=0.230 ; \mathrm{p}<0.05)$. This implies that a unit change in information management increases organizational performance by 0.230 units. The research findings therefore supports the argument that information sharing and connectivity has a link to performance of suppliers which in turn increases organizational performance.

Table 1 Inferential Results

\begin{tabular}{|c|c|c|c|c|c|c|}
\hline & \multicolumn{2}{|c|}{ Unstandardized Coefficients } & \multicolumn{3}{|c|}{ Standardized Coefficients } & \multirow[b]{2}{*}{ Correlation } \\
\hline & B & Std. Error & Beta & $\mathrm{T}$ & Sig. & \\
\hline (Constant) & 1.374 & 0.378 & & 3.632 & 0.000 & \\
\hline Environmental uncertainty & 0.527 & 0.105 & 0.450 & 5.034 & 0.000 & $0.501 * *$ \\
\hline Information management & 0.250 & 0.085 & 0.230 & 2.961 & 0.004 & $0.582 * *$ \\
\hline \multicolumn{7}{|c|}{ Model Summary } \\
\hline R Square & 0.467 & & & & & \\
\hline Adjusted R Square & 0.451 & & & & & \\
\hline $\mathrm{F}$ & 28.732 & & & & & \\
\hline Sig. & 0.000 & & & & & \\
\hline
\end{tabular}

* Significant at 0.5 level (2-tailed), ** Significant at 0.01 level (2-tailed)

\section{CONCLUSION AND RECOMMENDATIONS}

The study sought to investigate the effect of supply chain resilience on the organization's performance. This was accomplished through the testing of the hypothesized model, which was developed based on detailed reviews of past literatures. This study attempted to close the research gap by looking at effects the supply chain resilience has on organizational performance using the two constructs that is environmental uncertainty and information management.

The first finding of this research is that there is need to emphasize the importance of upholding and sustaining supply chain resilience in today dynamic and competitive environment. Resiliency is considered as the key to gaining competitive advantage for manufacturing firms. Environmental dynamism present not only challenges to the going concern of the business, but it has a positive impact full of opportunities to firms. In order for managers to realize performance in their organization they must critically analyze environmental uncertainty in consumers needs, producers expectation and innovation.
Secondly, the finding of the study was that, information management positively affects organizational performance. As information sharing increases the collaboration among the supply chain partners, it also increases connectivity which results to reduced customer demand fluctuations and uncertainties which leads to increased organizational performance. Moreover, effective collaboration can be achieved through the use of digital communication. For organization to flourish in today's global market; there is need for organization to develop strategic alliances and partnerships with suppliers and customers.

\section{Implication of the Study Findings}

Study findings uncovered that supply chain versatility significantly affects firm's performance. Resilience suggests adaptability and dexterity; its suggestion ought to stretch out past process upgrade to principal choices on sourcing and foundation of a more cooperative store network connections in light of far more prominent straightforwardness of data.

Along these lines, it is all more vital for managers to procure open and agreeable capabilities to be connected when seeing 
someone, or to actualize reconciliation in a way that does not make conditions. As the framework "supply chain" is moderate shape between the central organization and its condition, the discoveries of this exploration underline the significance of a planned approach among supply chin individuals to accomplish resilience.

The study recommends that organizations should completely perceive the idea of fundamental supply chain flexibility and have proceeded with center around looking for proficient changes through "lean" arrangements. Be that as it may, new need has risen for business arranging. This need is the scan for supply chain methodologies that encapsulate a huge higher level of versatility. It is also recommended that the purchasing and supplies managers should be innovative and apply new ideas to the products, process and other aspects of supply chain activities and obtain appropriate information within its internal and external environment and evaluate performance measures in ways that can steer high firm competitiveness and enhance performance.

The study suggests further research to be done on adoption studies to establish why organizations are not fully embracing the collaborative strategy with the suppliers. Moreover the findings of this study could be recreated under various relevant conditions, for example, international settings or dyadic or production network organize level of investigation for instance, strength could be additionally considered with regards to dyadic purchaser provider connections.

\section{REFERENCES}

[1] Acedo, F. J., Barroso, C., \& Galan, J. L. (2006). The resource-based theory: dissemination and main trends. Strategic management journal, 27(7), 621-636.

[2] Barney, J. (1991). Firm resources and sustained competitive advantage. Journal of management, 17(1), 99-120.

[3] Barney, J. B., \& Clark, D. N. (2007). Resource-based theory: Creating and sustaining competitive advantage. Oxford University Press on Demand.

[4] Business Continuity Institute.( 2011). Supply Chain Resilience 2011. 3rd Annual Survey, November 2011. http://www. bcipartnership.com/supplychainform.html.

[5] Chen, I. J., \& Paulraj, A. (2004). Towards a theory of supply chain management: the constructs and measurements. Journal of operations management, 22(2), 119-150.

[6] Christopher, M., \& Peck, H. (2004). Building the Resilient Supply Chain. The International Journal of Logistics Management, 15(2), $1-14$.

[7] Cook, L. S., Heiser, D. R., \& Sengupta, K. (2011). The moderating effect of supply chain role on the relationship between supply chain practices and performance: An empirical analysis. International Journal of Physical Distribution \& Logistics Management.

[8] Crook, T. R., Ketchen Jr, D. J., Combs, J. G., \& Todd, S. Y. (2008). Strategic resources and performance: a meta-analysis. Strategic management journal, 29(11), 1141-1154.
[9] Johnson, M. W., Christensen, C. M., \& Kagermann, H. (2008). Reinventing your business model. Harvard business review, 86(12), 57-68.

[10] Jüttner, U., Christopher, M., \& Godsell, J. (2010). A strategic framework for integrating marketing and supply chain strategies. Management, 21(1), 104-126.

[11] Ketchen Jr, D. J., \& Hult, G. T. M. (2007). Bridging organization theory and supply chain management: The case of best value supply chains. Journal of operations management, 25(2), 573-580.

[12] Kothari, C. R. (2004). Research methodology: Methods and techniques. New Age International.

[13] Lambert, R., Leuz, C., \& Verrecchia, R. E. (2007). Accounting information, disclosure, and the cost of capital. Journal of accounting research, 45(2), 385-420.

[14] Li, S., Ragu-Nathan, B., Ragu-Nathan, T. S., \& Rao, S. S. (2006). The impact of supply chain management practices on competitive advantage and organizational performance. Omega, 34(2), 107124.

[15] Linnenluecke, M., \& Griffiths, A. (2010). Beyond adaptation: resilience for business in light of climate change and weather extremes. Business \& Society, 49(3), 477-511.

[16] Mentzer, J. T., Min, S., \& Bobbitt, L. M. (2004). Toward a unified theory of logistics. International Journal of Physical Distribution \& Logistics Management.

[17] Mentzer, J. T., Stank, T. P., \& Esper, T. L. (2008). Supply chain management and its relationship to logistics, marketing, production, and operations management. Journal of business logistics, 29(1), 31-46.

[18] Morris, M., \& Carter, C. R. (2005). Relationship marketing and supplier logistics performance: an extension of the key mediating variables model. Journal of Supply Chain Management, 41(4), 3243.

[19] Olavarrieta, S., \& Ellinger, A. E. (1997). Resource-based theory and strategic logistics research. International Journal of Physical Distribution \& Logistics Management.

[20] Pettersen, J. (2009). Defining lean production: some conceptual and practical issues. The TQM journal.

[21] Priem, R. L., \& Butler, J. E. (2001). Is the resource-based "view" a useful perspective for strategic management research?. Academy of management review, 26(1), 22-40.

[22] Tan, K. C. (2002). Supply chain management: practices, concerns, and performance issues. Journal of Supply Chain Management, $38(4), 42-53$

[23] Tan, K. C. (2002). Supply chain management: practices, concerns, and performance issues. Journal of Supply Chain Management, $38(4), 42-53$.

[24] Teece, D. J. (2007). Explicating dynamic capabilities: the nature and microfoundations of (sustainable) enterprise performance. Strategic management journal, 28(13), 1319-1350.

[25] Wieland, A., \& Wallenburg, C. M. (2012). Dealing with supply chain risks: Linking risk management practices and strategies to performance. International journal of physical distribution \& logistics management.

[26] Womack, J. P., Jones, D. T., \& Roos, D. (1990). The machine that changed the world, Rawson Associates. New York, 323, 273-287.

[27] Yu, Z., Golpîra, H., \& Khan, S. A. R. (2018). The impact of GSCM on manufacturing enterprise's performance. Journal of Advanced Manufacturing Systems, 17(04), 445-459.

[28] Zeithaml, V. A., Bolton, R. N., Deighton, J., Keiningham, T. L., Lemon, K. N., \& Petersen, J. A. (2006). Forward-looking focus: can firms have adaptive foresight?. Journal of Service Research, 9(2), 168-183. 